\title{
Introduction: Why "Revisit" Medical Humanism in Renaissance Europe?
}

Introduction: Pourquoi "revisiter" l'humanisme médical dans l'Europe de la Renaissance?

\section{Caroline Petit}

\section{(2) OpenEdition}

\section{Journals}

Electronic version

URL: https://journals.openedition.org/aes/3633

DOI: 10.4000/aes.3633

ISSN: 2258-093X

Publisher

Laboratoire LISAA

\section{Electronic reference}

Caroline Petit, "Introduction: Why "Revisit" Medical Humanism in Renaissance Europe?", Arts et Savoirs [Online], 15 | 2021, Online since 25 June 2021, connection on 17 December 2021. URL: http:// journals.openedition.org/aes/3633 ; DOI: https://doi.org/10.4000/aes.3633

This text was automatically generated on 17 December 2021.

Centre de recherche LISAA (Littératures SAvoirs et Arts) 


\title{
Introduction: Why "Revisit" Medical Humanism in Renaissance Europe?
}

\author{
Introduction: Pourquoi "revisiter" l'humanisme médical dans l'Europe de la \\ Renaissance?
}

Caroline Petit

The following articles mostly arise from panels that should have taken place at the Renaissance Society of America (RSA)'s annual meeting in 2020 in Philadelphia. In light of the pandemic, the meeting had to be cancelled: but we could not let go of all the hard work that had gone into our panel preparation. This gave rise to the idea of a collection on "revisiting medical humanism", as per the RSA panel title I had sponsored as Discipline Representative for Medicine and Science. Let this collection of papers be a token of our continued enthusiasm and love for the RSA and not just medical humanism!

I am extremely grateful to the editors of Arts et Savoirs for accepting this special issue and providing the time and resources to publish it so professionally and speedily. I owe special thanks to Carmen Husti for her help in the final stages of publication and to Aidan Norrie (Warwick), for providing an extremely thorough revision of the English in record time. I would like to extend my warmest thanks to the anonymous referees for providing helpful remarks and suggestions in an especially busy and complicated year for all.

Finally, none of this would have seen the light were it not for the constant support and encouragement I received in the Centre for the Study of the Renaissance (CSR) at the University of Warwick from its two most recent directors: Ingrid de Smet encouraged the unredeemable Classicist I am to persevere in Renaissance Studies and to serve the RSA as Discipline Representative. David Lines kindly trusted me with the post of Director of Graduate Studies in the CSR and was a constant source of advice and motivation. Finally, I am indebted to the CSR for providing financial and logistical support on several occasions, including the research that led to my article in this volume.

1 Why focus on "medical humanism" in 2021, a notion that may appear familiar to all and remote from current trends in research? Do we not know everything about the genesis of the Aldine editions of Dioscorides, Galen, and Hippocrates? About the great 'medical 
philologists' of the sixteenth century, from Leoniceno to Scaliger? About the quarrel between Arabists and Hellenists? The answers to these questions are far from clear, and this collection of articles expresses a shared, deep-seated conviction that many shadows and gaps remain in our knowledge.

Due to the long period under examination here (about a century, from the midfifteenth century to the late sixteenth century), we understand medical humanism as the confluence of medicine and humanism in the broadest possible way. The rediscovery and revival of ancient Greek medicine forced humanists to address specific challenges in translation and interpretation. We therefore look at the Greek foundations of medical humanism, as would be expected, but with a stronger focus on the Latin translations of ancient medical texts and their impact on humanist thought and authorship as well as on the medical field. Although discipline boundaries are irrelevant in the Renaissance world of the learned, the practical, observational dimension of medicine shaped a somehow distinct strand of humanism, which could be termed "medical humanism". This is what we set out to "revisit", in light of new or hitherto neglected evidence, or by adopting fresh angles on well-known problems and figures ${ }^{1}$.

of course, at first glance this project may seem counter-intuitive in the field of Renaissance studies. Recent scholarly work has ambitiously mapped out the world of knowledge in the sixteenth and early seventeenth centuries, highlighting the technological improvement of print, the circulation of scholars and the building of networks, the practicalities of the book trade and their impact on many an individual library ${ }^{2}$. The boundaries of the Renaissance have expanded, now opening onto the various "new worlds" that interacted with Europe: this, too, is having an impact on our understanding of Renaissance medicine in a global context ${ }^{3}$. Comprehensive and synoptic studies seem to be on the rise, yet detailed studies of both famous and less famous medical authors have also appeared ${ }^{4}$. Meanwhile, literary and interdisciplinary endeavours have further explored the permeability of Renaissance literature to medical thought, raising various questions about the fertile ways that medicine, rhetoric, and literature interact ${ }^{5}$. Witnessing this increasingly confident treatment of Renaissance medicine "in context" is exhilarating. Yet for those of us closely reading manuscripts, early editions, or humanist translations of medical texts, either in Latin or in the vernacular, and trying to establish connections with their cultural and intellectual context, it is not rare to fall down a rabbit's hole or face an astonishing gap in scholarship. Humanist translations of Galenic texts, for instance, are not yet fully mapped out, in spite of extremely helpful new tools ${ }^{6}$. This, in turn, affects our understanding of the intellectual stature of a physician like Josephus Struthius, a Polish physician whose endeavours in the pulse prepared the discoveries of Harvey on blood circulation. Struthius moved to Padua, where he found success reading and teaching medicine, before moving back to the Polish court (and meeting Soliman II in the process). But in his prime, he was also a translator of neglected texts of the Galenic corpus - yet no detailed study of his philological work was ever attempted, until Simone Mucci's article in this special issue. A trope in academic writing is that such authors and works may have been forgotten for a reason. Yet Mucci's article shows that Struthius's activity as a translator is not anecdotal: it illuminates power struggles in academe, through the numerous, scornful attacks against rival translator Guinter of Andernach embedded in the translation; it reveals a vindictive, Galen-like persona 
created by Struthius, with a view to establish his authority; it sheds light on his translation strategies, which happen to diverge significantly from existing works by others; it ties in with Struthius's later and more famous works, such as his treatise on the pulse. This is an original contribution, however limited in scope, to the intellectual and medical history of Renaissance Europe.

Other articles in this issue achieve similarly interesting results and link together through their focus on medical humanism. The foundation of humanist work on medical texts, as is well known, was facilitated by the migration of Greek scholars from a crumbling Byzantium, and the books they carried with them. Cardinal Bessarion played a major role, through a more systematic attempt at collecting, copying, and safeguarding Greek manuscripts in a variety of subjects. Yet the medical manuscripts that Bessarion had copied - and are now housed in the Biblioteca Nazionale Marciana have not yet delivered all their secrets: proof of this is brought by Ciro Giacomelli's article, which revisits the evidence from the Venice manuscripts themselves and from Bessarion's correspondence. Giacomelli is able to reconstruct, on the basis of his own examination of manuscripts and thanks to many recent studies in Greek palaeography, the sources used by Bessarion's scribes, their provenance, and at times their relevance for the medical humanists who owned or annotated them - for example, Ermolao Barbaro (1454-1493). The emerging picture reveals many new findings, and provides a solid foundation for future research into the use made by humanists of Bessarion's collection.

5 The same foundational decades of the late fifteenth century are explored from a different perspective by Gastón Javier Basile's enlightening study of the debates around translations in the late fifteenth century. As Basile demonstrates, examining the humanist translations (including those we have lost) of medical and natural philosophical texts, and the discourse on translation they have generated, sheds new light on the humanist movement. Unlike literary texts, which could be handled and discussed from the standpoint of style and rhetoric, scientific texts raised new issues: as Basile puts it, "the question of terminology, the relation between res and verba, specific translation strategies, genre awareness, among others" arose in humanist discourse as a result of the challenges put to them by scientific texts. Integrating such a corpus of texts into the study of translation in the Renaissance allows for sharper insights into humanism; conversely, it is illuminating to consider Leoniceno's work through the lens of wider debates on translation in his time, thus re-assessing his lasting impact on Renaissance translations of scientific texts.

6 A substantial bibliography follows the name of Giuseppe Manardi (1462-1536) or Manardo, one of the better-known medical humanists at Ferrara and follower of Leoniceno's ${ }^{7}$. His French admirer and friend, Symphorien Champier (c. 1471-1539), is far less studied - especially if one takes into consideration the sheer number of medical titles in his œuvre (35). Both are known to have sided with the Greeks against the Arabs, but who remembers the influence of the work of Mesuë in Renaissance medicine, a medical authority who scholars revered and who was still heavily cited in the seventeenth century? Dorothea Heitsch re-visits the reception of the works attributed to Mesuë, with special attention to Manardo and Dubois' takes on the "database" represented by those works. Acknowledging the considerable success in print of the Opera Mesuae, she argues that the re-fashioning, updating, and translating of Mesuë throughout the sixteenth century amounts to providing "a paradigm of medical 
anthropology". Echoing the debates highlighted by Basile, she analyses some of the translations and annotations by Manardo and Dubois that fed into their own practitioners' work. Her study allows her to convincingly conclude that "the Opera Mesuae proves that the quarrel between humanists and Arabists is not as divisive as it may have been made out" on both sides of the Alps.

7 From Ferrara and Venice to Lyon, and back, is the journey undertaken by Symphorien Champier's works. A keen admirer of his Italian professors - especially Manardi Symphorien became in a couple of decades a key proponent of Greek medicine. He was not a translator himself, but as a popular writer and notorious personality in sixteenthcentury Lyon, he amply facilitated the editorial activity around ancient doctors, especially his hero Galen. As a prelude to Mucci's analysis of Struthius as a new Galen, Caroline Petit's article explores Galen in Symphorien Champier's works, as a historical figure, a role model, and a medical authority. The article analyses the role of Champier in diffusing and popularising Galen, whilst investigating the impact of Galen's rediscovery from 1490 to the 1530 s on the intellectual trajectory of Symphorien Champier. Champier's involvement in this editorial activity and the medical polemics of the time embodies a forgotten, but influential, form of "medical humanism" that may have culminated in inspiring Rabelais's literary creation. A physician and author, born and bred in the scholastic tradition, he was a practitioner as passionate about the revival of ancient medical texts as he was about providing the best possible care.

This ambivalence of Renaissance physicians as humanists and practitioners is further exemplified in Allen Shotwell's study of a particular anatomical text, Galen's De ossibus in the context of controversies between prominent anatomists Dubois and Vesalius. Considered nowadays a minor work among Galen's anatomical works, De ossibus belongs to the series of short treatises on anatomy for beginners. According to Allen Shotwell's enquiry, however, the opuscule was incredibly popular and generated several translations, in Latin and in French, and commentaries in France and Spain, probably due to high demand. It was a major source for Vesalius, yet it also became the seat of medical and educational controversy in the 1550s, between Dubois (attacking his former student Vesalius) and defenders of Vesalius such as Collado in Spain. In this article, we again see the close links between translations, medical debates, and practices in sixteenth century Europe in a way that echoes and amplifies the case observed by Simone Mucci.

Our final article casts a retrospective, erudite look on the very notion of 'medical humanism' in the long sixteenth century. According to Vivian Nutton, "the reader cannot but worry about the laxness of a term that can cover almost two centuries and authors as different as Leonhard Fuchs (1501-1566) and Sanctorius Sanctorius (1561-1636), let alone Paracelsus (1493-1541), and can apply equally to a general education and to a belief in specific ideas and practices". Exploring the practices of physicians around texts, knowledge, objects, and bodies, Nutton demonstrates the extreme volatility of the concept, in view of the sheer diversity of opinions, reactions, and allegiance that can be observed in 'medical' Europe from the late fifteenth century to the early seventeenth century. There is a "Latin" as well as a "Greek" medical humanism, and lines may be drawn to distinguish between different understandings of medical humanism. But should we embrace the rich connotations of "medical humanism", or use cautiousness? Readers will judge. 
10 As I hope the above description will have made clear, this volume has both used and bypassed the usual landmarks of "medical humanism" and moved away from such towering figures as Leoniceno, Scaliger, or Linacre. Instead, our studies revisit 'medical humanism' in a variety of ways and by focusing on often unexpected material: the Greek medical manuscripts owned, copied, and used by the humanists; translation techniques, from Poliziano to the lesser-known Josephus Struthius; the prevalence of contemporary medical debates in translations of Galenic works; the interplay between medicine, literature, and enduring non-Greek medical authorities such as Mesuë; and the links between texts, translations, and medical practice. Dorothea Heitsch's description of Mesuë being "at the crossroads of translation, exchange, humanistic rhetoric, the medical schools of Italy and France, printing, and transnational conversations" could also apply to this entire collection. Our conclusions invite further interdisciplinary research and encounters. Thus, lost or unseen streams and figures of "medical humanism" may re-surface. Medical humanism, we believe, continues to be a valid notion to explore and question, as long as it is approached with creativity.

\section{NOTES}

1. Vivian Nutton provides an overview of the literature on "medical humanism" in the final article of this volume.

2. To cite but a few significant book-length studies in and around medicine in early modern times: Paula Findlen (ed.), Empires of Knowledge. Scientific Networks in the Early Modern World, London, Routledge, 2019; Mary Lindemann, Medicine and Society in Early Modern Europe, Cambridge, Cambridge University Press, 2010; Gianna Pomata \& Nancy G. Siraisi (eds), Historia: Empiricism and Erudition in Early Modern Europe, Cambridge, Mass., MIT Press, 2005; Ian Maclean, Logic, Signs and Nature in the Renaissance: The Case of Learned Medicine, Cambridge/NY, Cambridge University Press, 2001; Sachiko Kusukawa \& Ian Maclean (eds), Transmitting knowledge: words, images and instruments in early modern Europe, Oxford Warburg Series, Oxford University Press, 2006; Brian Ogilvie, The Science of Describing. Natural History in Renaissance Europe, Chicago, The university of Chicago Press, 2006.

3. In the area of plants and pharmacology, see especially Samir Boumediene, La colonisation du savoir. Une histoire des plantes médicinales du « Nouveau Monde » (1492-1750), Vaulx-en-Velin, Éditions des Mondes à faire, 2016; Paula De Vos, Compound Remedies. Galenic Pharmacy from the Ancient Mediterranean to New Spain, Pittsburgh, University of Pittsburgh Press, 2020.

4. Vesalius continues attracting scholarly attention; anatomy and surgery have been popular. Vivian Nutton (ed), Principles of Anatomy according to the Opinion of Galen by Johann Guinter and Andreas Vesalius, London and New York, Routledge, 2017; Cynthia Klestinec, Theaters of Anatomy: Students, Teachers, and Traditions of Dissection in Renaissance Venice, Baltimore, Johns Hopkins University Press 2011; Cynthia. Klestinec \& Dominico Bertoloni Meli (eds), Renaissance Surgery: Between Learning and Craft, special issue of the Journal of the History of Medicine and Allied Sciences, vol. LXXII-1, 2017. For a productive combined exploration of anatomy, art and Venetian society, see Gabrile Matino \& Cynthia. Klestinec (eds), Art, Faith and Medicine in Tintoretto's Venice, Marsilio, Venice, 2018. 
5. See for example Stephen Pender \& Nancy S. Struever (eds), Rhetoric and Medicine in Early Modern Europe, London and New York, Routledge, 2012. In the field of French literature specifically, see for example Judy Kem, Pathologies of Love. Medicine and the Woman Question in Early Modern France, University of Nebraska Press, 2019; Dorothea Heitsch, Writing as Medication in Early Modern France, Heidelberg, Universitatsverlag Winter, 2017; Véronique Montagne, Médecine et rhétorique à la Renaissance. Le cas du traité de peste en langue vernaculaire, Paris, Classiques Garnier (Bibliothèque de la Renaissance, $\left.n^{\circ} 17\right), 2017$. Following into the footsteps of Roland Antonioli, specialists of Rabelais are re-examining the medical and botanical material in connection with the genesis of the famous "novels".

6. See for example the website curated by Stefania Fortuna: galenolatino.com. Fortuna's excellent publications on the editions and translations of Galen in the Renaissance have tremendously improved R. J. Durling's classic "Census" of 1962 and expanded our understanding of medical humanism: see for instance Stefania Fortuna, "The Prefaces to the First Humanist Medical Translations", Traditio, n 62, 2007, p. 317-335; Id., "Galeno latino, 1490-1533", Medicina nei Secoli, $\mathrm{n}^{\circ} 17$, 2005, p. 469-505. Cf. Vivian Nutton, John Caius and the Manuscripts of Galen, Cambridge, University Press, 1987.

7. Cf. Vivian Nutton, "The Rise of Medical Humanism in Ferrara", Renaissance Studies, vol. XI-1, 1997, (with further literature).

\section{AUTHOR}

\section{CAROLINE PETIT}

University of Warwick 